\title{
KESTABILAN PENYETARAAN HORIZONTAL DENGAN METODE LINIER BERDASARKAN PROPORSI KELOMPOK GANDENG
}

\author{
Yustiandi \\ Universitas Negeri Jakarta \\ Wardani Rahayu \\ Universitas Negeri Jakarta \\ Yetti Supriyati \\ Universitas Negeri Jakarta
}

\footnotetext{
Alamat Korespondensi

J. Pemuda 2, No. 36,

Rawamangun,

Jakarta Timur, DKI Jakarta

Indonesia

e-mail:

yustiandi@yahoo.com
}

\begin{abstract}
This study aims to determine the difference of stability of horizontal equiting of linear method with the $15 \%, 20 \%, 25 \%$, and $30 \%$ anchor group and with 50 times replications. This research is done by analyzing the students' physics learning scores. The population in this research is all high school students of grade 11 science program in Pandeglang District and the sample is students grade 11 in SMAN 1 Pandeglang, SMAN 2 Pandeglang, SMAN 4 Pandeglang, SMAN 6 Pandeglang, and SMAN CMBBS which amounts to 800 people taken simple random with replacement. The research method used is the experimental method by comparing the Root Mean Square Difference (RMSD) value of the equation based on the difference of the anchor group. The results showed that there was a difference of horizontal equiting stability with linear method with anchor group proportion 15\%,20\%,25\%, and 30\% with 50 times replications. Post hoc test are used to determine whether there are differences between groups if each group is compared. Based on post hoc test, it is known that the equating for the anchor group proportion $15 \%$ is most stable compared with the stability of equating for the anchor group proportion $20 \%$, $25 \%$, and $30 \%$ coupling with replication 50 times.
\end{abstract}

\section{Keywords}

Stability, RMSD, Linier Equiting, Anchor Group

\section{ABSTRAK}

Penelitian ini bertujuan untuk mengetahui perbedaan kestabilan penyetaraan horizontal metode linier dengan proporsi kelompok gandeng 15\%, 20\%, 25\%, dan 30\% dengan replikasi sebanyak 50 kali. Penelitian ini dilakukan dengan menganalisis sekor hasil belajar fisika siswa. Populasi pada penelitian ini adalah seluruh siswa SMA kelas XI program IPA di Kabupaten Pandeglang, sedangkan sampel penelitian adalah siswa kelas XI IPA di SMAN 1 Pandeglang, SMAN 2 Pandeglang, SMAN 4 Pandeglang, SMAN 6 Pandeglang, dan SMAN CMBBS yang berjumlah 800 orang yang diambil secara acak sederhana dengan pengembalian. Metode penelitian yang digunakan adalah metode eksperimen dengan membandingkan nilai Root Mean Square Difference (RMSD) dari hasil penyetaraan berdasarkan perbedaan proporsi kelompok gandeng. Hasil penelitian menunjukkan bahwa terdapat perbedaan kestabilan penyetaraan horizontal dengan metode linier dengan proporsi kelompok gandeng 15\%, 20\%, 25\%, dan 30\% dengan replikasi sebanyak 50 kali. Uji lanjut digunakan untuk mengetahui ada tidaknya perbedaan antar kelompok jika masing-masing kelompok dibandingkan. Berdasarkan uji lanjut, diketahui bahwa penyetaraan dengan proporsi kelompok gandeng $15 \%$ paling stabil dibandingkan dengan penyetaraan dengan proporsi kelompok gandeng 20\%, 25\%, dan 30\% dengan replikasi sebanyak 50 kali.

\section{Kata kunci}

Kestabilan, RMSD, Penyetaraan Linier, Kelompok Gandeng 


\section{Pendahuluan}

Penilaian merupakan salah satu bagian penting dalam pembelajaran karena penilaian dapat menentukan kualitas pembelajaran, sehingga jika kita ingin meningkatkan kualitas pembelajaran, maka salah satu cara yang dapat dilakukan adalah dengan meningkatkan kualitas penilaian.

Terdapat beberapa masalah ketika hendak melakukan penilaian pada kelas paralel yang dilakukan dalam waktu yang berbeda, diantaranya adanya kebocoran soal. Untuk mengatasi kebocoran soal, pendidik membuat beberapa alat tes atau paket soal berdasarkan kisi - kisi yang sama sehingga pendidik menganggap bahwa setiap paket soal sudah setara. Tetapi pada kenyataannya, walaupun alat tes tersebut dibuat berdasarkan kisi - kisi yang sama, alat tes tersebut masih memungkinkan memiliki tingkat kesulitan yang bervariasi. Siswa akan mendapatkan nilai yang tinggi ketika dia mendapatkan soal yang bisa dia kerjakan, sebaliknya siswa akan mendapatkan nilai yang kecil ketika dia mendapatkan soal yang tidak bisa dia kerjakan. Azwar (2007) berpendapat bahwa hasil tes yang diperoleh dengan cara yang tidak adil tidak dapat memberikan informasi untuk mengetahui prestasi yang sebenarnya serta dapat memberikan hasil yang keliru mengenai keberhasilan belajar siswa.

Permasalahan di atas dapat diatasi dengan penyetaraan sekor. Penyetaraan adalah penyesuaian sekor antara dua tes yang berbeda yang mengukur atribut yang sama agar dapat diperbandingkan dalam skala yang sama (Crocker, Algina, Kolen, Brennan, Hambleton, Swaminathan, Rogers, Naga).
Penyetaraan sekor secara klasik memiliki dua metode, yaitu: linier dan equipersentil. Menurut Naga (2013), pada penyetaraan linier, hubungan sekor setara dan sekor asal adalah linier. Selain itu, terdapat dua arah dalam penyetaraan skor, yaitu: vertikal dan horizontal. Arah penyetaraan horizontal dilakukan terhadap responden setara dengan atribut yang juga setara.

Berdasarkan rancangan penyetaraan yang dikemukakan Naga (2013), terdapat butir gandeng dan kelompok gandeng yang masing-masing dapat mempengaruhi keakurasian penyetaraan.

Julia Kopf, Achim Zeileis, dan Carolin Strobl (2014) menyatakan bahwa proporsi anchor sangat berpengaruh terhadap keakurasian penyetaraan. Beberapa penelitian telah dilakukan untuk membuktikan proporsi butir gandeng yang paling akurat, seperti penelitian yang dilakukan Supriyati (2003) yang menyatakan bahwa proporsi anchor item 20\% memberikan variansi skor yang paling stabil. Sementara belum ada yang meneliti tentang kelompok gandeng.

Penelitian ini bertujuan untuk mengetahui apakah terdapat perbedaan kestabilan penyetaraan horizontal dengan metode linier antara penyetaraan dengan proporsi kelompok gandeng 15\%, 20\%, 25\%, dan 30\% serta ingin mengetahui manakah di antara proporsi kelompok gandeng tersebut yang menghasilkan kestabilan penyetaraan tertinggi.

\section{Metode Penelitian}

Metode yang digunakan dalam penelitian ini adalah metode yang menggunakan dua jenis variabel, yaitu: variabel bebas dan variabel terikat. Variabel bebas yang digunakan adalah proporsi 
kelompok gandeng $(15 \%, 20 \%, 25 \%$, dan $30 \%$. Sementara variabel terikatnya adalah keakurasian penyetaraan horizontal dengan metode linier yang dinyatakan dengan Root Mean Square Difference (RMSD).

Populasi penelitian ini adalah seluruh siswa kelas XI IPA di Kabupaten Pandeglang dan yang menjadi sampelnya adalah siswa kelas XI IPA di SMAN CMBBS, SMAN 1 Pandeglang, SMAN 2 Pandeglang, SMAN 4 Pandeglang, dan SMAN 6 Pandeglang yang berjumlah 800 orang yang diambil secara acak sederhana dengan pengembalian.

\section{Hasil Penelitian dan Pembahasan}

Nilai RMSD untuk masing-masing proporsi kelompok gandeng dengan 50 kali replikasi, ada pada Tabel 1. berikut ini:
Instrumen dalam penelitian ini menggunakan dua instrumen tes hasil belajar mata pelajaran fisika $X$ dan $Y$ yang berasal dari kisi-kisi yang sama. Setelah melalui uji validitas isi dan butir, diambil masing-masing 20 soal untuk tiap paket. Reliabilitas instrumen $X$ memiliki koefisien 0,865, sedangkan reliabilitas instrumen $Y$ memiliki koefisien 0,858 , sehingga kedua instrumen tes dinyatakan reliabel untuk dipergunakan.

Data skor hasil belajar fisika, kemudian dihitung nilai RMSD untuk masing-masing proporsi kelompok gandeng dengan 50 kali replikasi.

Tabel 1. Nilai RMSD Hasil pada 50 kali Replikasi

\begin{tabular}{ccccc}
\hline & $\mathbf{1 5 \%}$ & $\mathbf{2 0 \%}$ & $\mathbf{2 5 \%}$ & $\mathbf{3 0 \%}$ \\
\hline Variansi & 0,364 & 0,393 & 0,461 & 0,557 \\
\hline Max & 2,528 & 2,944 & 2,931 & 3,443 \\
\hline Min & 0,261 & 0,365 & 0,109 & 0,229 \\
\hline
\end{tabular}

Pada Tabel 1, secara deskriptif nilai RMSD paling tinggi setelah 50 kali replikasi ditunjukkan oleh proporsi kelompok gandeng $30 \%$ dengan nilai 3,443. Sementara untuk nilai RMSD paling rendah ditunjukkan oleh proporsi kelompok gandeng 25\% dan $30 \%$ dengan nilai 0,109 . Nilai variansi RMSD paling besar dengan replikasi sebanyak 50 kali ditunjukkan oleh proporsi kelompok gandeng 30\% dengan nilai 0,557 dan nilai variansi RMSD paling kecil dengan replikasi 50 .
Variansi RMSD paling kecil dengan replikasi sebanyak 50 kali ditunjukkan oleh proporsi kelompok gandeng $15 \%$ dengan nilai 0,364.

Berdasarkan data di atas, dapat disimpulkan bahwa penyetaraan dengan proporsi kelompok gandeng 15\% memberikan hasil yang paling akurat dan stabil dibandingkan dengan proporsi kelompok gandeng 20\%, $25 \%$, dan $30 \%$ dengan replikasi sebanyak 50 kali. 
Gambar 1. Nilai Variansi RMSD dengan 50 kali Replikasi

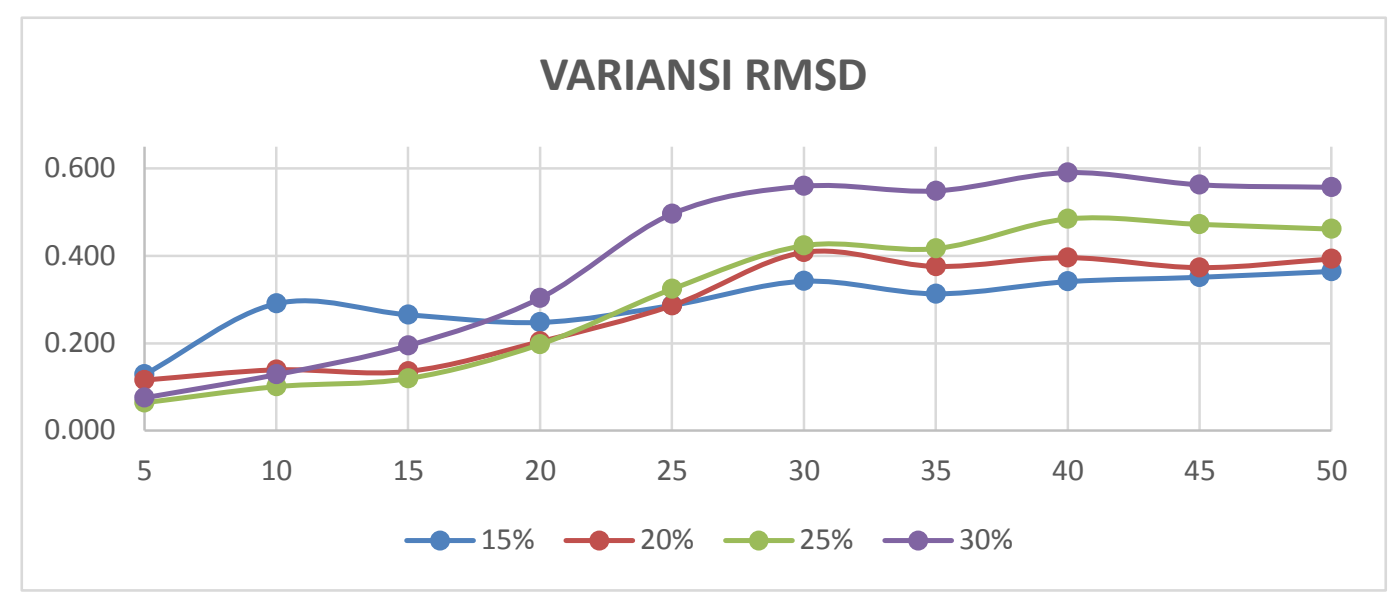

Berdasarkan Gambar 1 dapat dilihat kecenderungan grafik stabil setelah melakukan 30 kali replikasi. Dapat dilihat pula bahwa kelompok gandeng dengan proporsi $15 \%$ cenderung memiliki nilai RMSD paling kecil dibanding proporsi kelompok gandeng 20\%, 25\%, dan 30 dengan 50 kali replikasi. Hal ini berarti, penyetaraan dengan proporsi kelompok gandeng 15\% memberikan hasil yang paling stabil dibanding proporsi kelompok gandeng 20\%, $25 \%$, dan $30 \%$ untuk 50 kali replikasi.
Uji hipotesis secara empirik menggunakan statistik inferensial, yaitu: metode one way anova dan menghasilkan kesimpulan bahwa terdapat perbedaan nilai RMSD antara hasil penyetaraan linier pada kelompok gandeng dengan proporsi $15 \%$, 20\%, 25\%, dan 30\%.

Pengujian lanjutan dilakukan dengan menggunakan uji t-Dunnett. Berdasarkan hasil perhitungan, diperoleh data sebagai berikut:

Tabel 2. Hasil perhitungan uji $t$-Dunnett pada taraf signifikansi $\alpha=0,05$

\begin{tabular}{cccc}
\hline Hipotesis statistik & $\mathbf{T}_{\text {hitung }}$ & $\mathbf{T}_{\text {tabel }}$ & Kesimpulan \\
\hline $\begin{array}{l}\mathrm{H}_{0}: \mu_{15 \%} \leq \mu_{20 \%} \\
\mathrm{H}_{1}: \mu_{15 \%}>\mu_{20 \%}\end{array}$ & 0,055 & 2,576 & Terima $\mathrm{H}_{0}$ \\
\hline $\begin{array}{l}\mathrm{H}_{0:}: \mu_{15 \%} \leq \mu_{20 \%} \\
\mathrm{H}_{1}: \mu_{15 \%}>\mu_{20 \%}\end{array}$ & 0,112 & 2,576 & Terima $\mathrm{H}_{0}$ \\
\hline $\begin{array}{l}\mathrm{H}_{0:}: \mu_{15 \%} \leq \mu_{25 \%} \\
\mathrm{H}_{1}: \mu_{15 \%}>\mu_{25 \%}\end{array}$ & 0,484 & 2,576 & Terima $\mathrm{H}_{0}$ \\
\hline $\mathrm{H}_{0:} \mu_{25 \%} \leq \mu_{20 \%}$ & 0,057 & 2,576 & Terima $\mathrm{H}_{0}$ \\
$\mathrm{H}_{1}: \mu_{25 \%}>\mu_{20 \%}$ & 0,429 & 2,576 & Terima $\mathrm{H}_{0}$ \\
\hline $\mathrm{H}_{0:}: \mu_{30 \%} \leq \mu_{20 \%}$ & 0,372 & 2,576 & Terima $\mathrm{H}_{0}$ \\
$\mathrm{H}_{1}: \mu_{30 \%}>\mu_{20 \%}$ & & & \\
\hline $\mathrm{H}_{0:}: \mu_{30 \%} \leq \mu_{25 \%}$ & 0 \\
$\mathrm{H}_{1}: \mu_{30 \%}>\mu_{25 \%}$ & & & \\
\hline
\end{tabular}


Berdasarkan uji t-Dunnett diperoleh data bahwa keakurasian penyetaraan dengan proporsi kelompok gandeng 15\% menghasilkan penyetaraan yang paling stabil dibanding proporsi kelompok gandeng yang lain dengan replikasi sebanyak 50 kali.

Berdasarkan hasil penelitian tentang proporsi butir gandeng, diperoleh kesimpulan bahwa penyetaraan dengan proporsi butir gandeng 20\% merupakan proporsi yang menghasilkan kestabilan tertinggi, sementara pada penyetaraan yang menggunakan proporsi kelompok gandeng, penyetaraan dengan proporsi kelompok gandeng $15 \%$ menghasilkan kestabilan tertinggi pada replikasi sebanyak 50 kali.

\section{Kesimpulan}

Berdasarkan hasil pengujian hipotesis diperoleh kesimpulan bahwa keakurasian penyetaraan dengan proporsi kelompok gandeng $15 \%$ lebih stabil dibanding perangkat dengan proporsi kelompok gandeng 20\%, 25\%, dan 30\% dengan jumlah replikasi sebanyak 50 kali.

Berdasarkan kesimpulan di atas dan berbagai hal yang berkaitan dengan prosedur yang dilakukan dalam penelitian memberikan implikasi pada pengukuran dalam bidang pendidikan (psikometri), diantaranya adalah penyetaraan metode linier dapat digunakan untuk membuat peta kemampuan hasil belajar siswa.

\section{Daftar Pustaka}

Azwar, Saifuddin. Tes Prestasi. Yogyakarta: Pustaka Pelajar. Edisi II. 2007.

Croker, Linda and James Algina. Introduction to Classical and Modern Test Theory.
USA: Holt. Rinehart and Wiston. Inc. 1986.

Djaali dan Pudji Muljono. Pengukuran dalam bidang Pendidikan. Jakarta: PT. Grasindo. 2008.

Gusti, I Ngurah Agung. Statistika Penerapan Model Rerata - Sel Multivariat dan Model Ekonometri dengan SPSS. Jakarta: SAD Satria Bhakti, 2006.

Hambleton, R.K. and Swaminathan. Item Respon Theory Principle and Application Boston: MA Kluwer Inc. 1985.

Kolen, M. J. and Robert L. Brennan, Test Equating: Methods and Practice. New York Springer-Verlag, 1995.

Livingston, Samuel A. Equating Tes scores (without IRT). New Jersey: Educational Testing Service. 2004.

Naga, Dali S. Pengantar Teori Sekor Pada Pengukuran Mental. Jakarta: PT. Nagarani Citrayasa, 2013.

Wiersma, William and Stephen G. Jurs. Educational Measurement and Testing, 2nd edition. Boston: Allyn and Bacon. 1990. 